\title{
ANALISA PEMENUHAN HAK MASYARAKAT BERKEBUTUHAN KHUSUS DI KABUPATEN PONOROGO
}

\author{
Iqbal Akbar Imamudin ${ }^{1}$, Ardhana Januar Mahardhani ${ }^{1}$, Hadi Cahyono ${ }^{1}$ \\ ${ }^{1}$ Universitas Muhammadiyah Ponorogo, Ponorogo \\ *Corresponding Address: iqbalakbarnat28@gmail.com
}

Naskah diterima: 30 Oktober 2021| Disetujui: 8 November 2021 | Diterbitkan: 9 November 2021

\begin{abstract}
The focus of this research is on the role of the village government in guaranteeing and fulfilling the disability rights needs of people with mental retardation. This study uses qualitative methods, research data obtained through the methods of observation, interviews, and documentation as well as data analysis techniques that researchers use in this study is using an interactive model. This research was conducted in Karangpatihan Village, Balong District, Ponorogo Regency which has 97 mentally retarded persons in 2020. The results of this study indicate that the Karangpatihan Village government has given rights to mentally retarded persons with twenty-two types of rights in accordance with Law number 8 of 2016 on Persons with Disabilities. Furthermore, in its implementation, the Karangpatihan Village Government also collaborates through the triple helix concept, namely between academics, business, and the third government, synergizing with each other to provide the best services for people with disabilities.
\end{abstract}

Keywords: Village Government, Rights of Disabilities, Mentally retarded

\begin{abstract}
Abstrak: Fokus penelitian ini pada peran pemerintah desa dalam menjamin dan memenuhi kebutuhan hak disabilitas penyandang tunagrahita. Penelitian ini menggunakan metode kualitatif, data penelitian diperoleh melalui metode observasi, wawancara, dan dokumentasi serta teknik analisa data yang peneliti gunakan dalam penelitian ini adalah menggunakan model interaktif. Penelitian ini dilakukan di Desa Karangpatihan Kecamatan Balong Kabupaten Ponorogo yang memiliki penyandang tungrahita sebanyak 97 pada tahun 2020. Hasil dari penelitian ini diketahui bahwa pemerintah Desa Karangpatihan telah memberikan hak kepada penyandang tunagrahita dengan dua puluh dua jenis hak sesuai dengan Undang-Undang nomor 8 tahun 2016 tentang Penyandang Disabilitas. Selanjutnya dalam pelaksanaannya Pemerintah Desa Karangpatihan juga berkolaborasi melalui konsep triple helix yaitu antara akademik, bisnis, dan pemerintah yang ketiga saling bersinergi untuk memberikan layanan terbaik kepada penyandang disabilitas.
\end{abstract}

Kata kunci: Pemerintah Desa, Hak Disabilitas, Tunagrahita 


\section{PENDAHULUAN}

Setiap penduduk yang tersebar di seluruh dunia memiliki tumbuh kembang yang berbeda beda memiliki kondisi fisik dan kekurangan yang berbeda pula. Terdapat 15 dari 100 jiwa di dunia menyandang disabilitas dan dipastikan akan terus berkembang sejalan dengan meningkatnya angka harapan hidup penyandang disabilitas (Ismandari, 2019). Disabilitas di dunia juga menjadi perhatian sehingga terbitlah resolusi A/61/106 Majelis Umum Perserikatan Bangsa-Bangsa mengenai Convention on the Rights of Persons with Disabilities (CRPD) yang menjelaskan tentang hak perlindungan kaum disabilitas, lebih lanjut CRPD mengatur tentang bermacam-macam hak umum dan spesifik dari para penyandang disabilitas, dan mengatur kewajiban dan tugas negara sebagai unit yang mempunyai peran dalam pemenuhan hak para penyandang disabilitas seperti dalam penyesuaian kebijakan-kebijakan nasional, menyediakan reasonable accommodation, mewujudkan lingkungan yang disability inclusive, dan berbagai akses khusus dalam berbagai sektor baik fisik serta non-fisik. (Nasution \& Marwandianto, 2019).

Undang-undang Nomor 4 Tahun 1997 tentang Penyandang Cacat yang ada di Indonesia, ternyata belum dapat menjawab berbagai masalah yang timbul baik dalam rangka memberikan perlindungan, pemenuhan, dan penghormatan untuk hak penyandang disabilitas (Cahyono, 2017; Ndaumanu, 2020; Rika et al., 2020). Berbagai stigma dan pandangan terhadap penyandang disabilitas banyak yang hanya masih didasarkan pada rasa belas kasihan dan iba antar individu atau kelompok, belum ada yang secara komprehensif memberikan dorongan terlaksananya pelaksanaan kesamaan hak dan aksesbilitas serta kesempatan penuh terhadap penyandang disabilitas. Perwujudan dari pelaksanaan penegakan, pemajuan, perlindungan, serta pemenuhan hak penyandang disabilitas untuk seluruh aspek kehidupan, serta adanya ketentuan dari pengenaan sanksi administratif dan pidana serta larangan dan pengenaan sanksi yang maksimal juga belum mampu memberikan ruang yang luas kepada para penyandang disabilitas untuk dapat berekspresi. Banyaknya ketimpangan yang ada serta kasus terhadap disabilitas maka sebagai bentuk komitmen pada prinsip CRPD maka lahirlah Undang-Undang Nomor 8 Tahun 2016 tentang Penyandang Disabilitas (Ndaumanu, 2020).

Undang-undang nomor 8 tahun 2016 tentang Penyandang Disabilitas memberikan aturan terkait hak dari penyandang disabilitas, yaitu: hak untuk bebas dari eksploitasi, hak untuk bebas dari penyiksaan, kekerasan dan perlakuan semena-mena, perlakuan yang kejam tidak manusiawi dan merendahkan martabat manusia. Penyandang disabilitas dalam aturan yang ada secara formal juga mempunyai hak untuk mendapatkan penghormatan terhadap integritas dari mental serta fisik yang ada sesuai dengan kesamaan dengan orang lain normal pada umumnya, termasuk juga adanya hak untuk mendapatkan pelayanan sosial dan pelindungan untuk memberikan semangat kemandirian, 
serta pada saat kondisi darurat. Terbitnya undang-undang tentang penyandang disabilitas tersebut, tidak saja menjadi landasan hukum untuk penyandang disabilitas, tapi juga memberikan jaminan bahwa penyandang disablitas harus terbebas dari segala hal terkait dengan terhindar dari segala bentuk kekerasan, diskriminasi, dan ketidakadilan.

Dalam Undang-undang nomor 8 tahun 2016 tentang Penyandang Disabilitas disebutkan bahwa terdapat empat kriteria yang menyatakan jenis disabilitas di Indonesia yaitu disabilitas intelektual, disabilitas fisik, disabilitas sensorik, dan disabilitas mental. Diantara keempatnya terdapat disabilitas yang disebut sebagai tunagrahita atau disabilitas intelektual. Tunagrahita adalah kurangnya kemampuan intelektual pada individu yang menjadikan mereka berbeda dengan individu normal lainnya, pada umumnya mereka mempunyai tingkat kecerdasan intelektual di bawah rata - rata (Ramanda, 2008).

Peneliti memfokuskan kajian tentang penyandang disabilitas yaitu tunagrahita yang ada di Desa Karangpatihan Kecamatan Balong Kabupaten Ponorogo. Desa Karangpatihan memiliki penyandang tunagrahita terbanyak di Indonesia hingga sebutan 'desa idiot' pernah muncul di daerah tersebut (Safira \& Roseta, 2021). Desa Karangpatihan memiliki jumlah penduduk sebanyak 5.794 jiwa dengan sebaran laki - laki sebanyak 49,6\% dan perempuan sebanyak 50,4\%. Tercatat pada tahun 2020 terdapat 97 warga di Desa Karangpatihan yang menyandang disabilitas (Hasanah, 2020).

Sebutan 'desa idiot' bagi masyarakat Desa Karangpatihan merupakan sebutan yang sangat mendiskriminasikan sehingga banyak anggapan masyarakat dari luar Desa Karangpatihan bahwa penyandang tunagrahita akan tidak mampu untuk menghidupi keluarganya bahkan dirinya sendiri. kondisi seperti inilah yang akan memperparah kehiduapan sosial, ekonomi, psikis dan mental para penyandang tunagrahita. Keadaan yang semakin menyudutkan para penyandang tunagrahita ini akan menimbulkan rantai kemiskinan yang berkepanjangan. Mont berpendapat bahwa kondisi tunagrahita berpeluang terperangkap dalam kemiskinan yang diakibatkan dari minimnya aksesibilitas dalam memperoleh pekerjaan, keterlibatan dalam kelompok sosial bahkan juga mencakup kebutuhan belajar (Andriana, 2017).

Banyak penelitian yang telah dilaksanakan di Desa Karangpatihan, meskipun demikian penelitian terkait dengan pemberdayaan masyarakat dan kesehatan masyarakat (Anugrawati \& Pradana, 2021; Dewi, 2016; Gafara et al., 2017; Ramanda, 2008; Susanto, 2021; Widajati \& Purnama, 2020; Wulandari et al., 2019), dari berbagai penelitian yang telah dilakukan peneliti mencoba mengambil fenomena lainnya yaitu tentang perjuangan hak disabilitas masyarakat tunagrahita di Desa Karangpatihan, peneliti menemukan artikel relevan dengan yang sedang peneliti lakukan, yaitu strategi kepala desa dalam membangun good citizenship di Desa Karangpatihan (Rulianingsih \& 
Suyanto, 2018) dan upaya pemenuhan hak politik dalam Pemilihan Kepala Desa di Desa Karangpatihan tahun 2019 (Kusumawati \& Adi, 2020). Meskipun demikian kedua penelitian tersebut belum secara rinci melihat peran kepala desa jika dilihat dari Undang-undang nomor 8 tahun 2016 tentang Penyandang Disabilitas serta belum banyak membicarakan tentang perjuangan pemerintah desa dalam menyetarakan hak masyarakat penyandang tunagrahita. Sehingga penelitian ini akan mempertegas peran pemerintah desa dalam pemenuhan hak disabilitas penyandang tunagrahita di Desa Karangpatihan serta melihat langah kongkrit apa yang akan dilakukan oleh kepala desa dalam memberikan layanan terbaik untuk para penyandang disabilitas.

\section{METODE}

Jenis penelitian yang digunakan untuk menjawab permasalahan adalah penelitian kualitatif. Lokasi penelitian di Desa Karangpatihan, Kecamatan Balong, Kabupaten Ponorogo, Provinsi Jawa Timur. Sebagai informan kunci adalah kepala desa Karangpatihan yaitu bapak Eko Mulyadi. Pada penelitian ini data penelitian diperoleh melalui observasi, wawancara, dan dokumentasi. Observasi dilakukan pada saat peneliti melakukan kunjungan ke lokasi penelitian untuk menyesuaikan hasil wawancara yang telah peneliti dapat dengan kondisi di lapangan. Sedangkan dokumentasi peneliti peroleh dari foto, dokumen-dokumen baik yang berasal dari desa, artikel di koran, serta artikel di jurnal yang peneliti peroleh sebagai bentuk komparasi dengan penelitian sebelumnya. Penelitian ini menggunakan analisa data model interaktif Miles dan Huberman, yaitu analisa yang peneliti gunakan secara terus menerus sampai pada data jenuh, data jenuh di sini berarti peneliti sudah tidak memperoleh data atau informasi yang baru. Model interaktif ini dilakukan melalui aktivitas reduksi data, penyajian data, serta penarikan kesimpulan, dan verifikasi (Mahardhani, 2017)

\section{HASIL DAN DISKUSI}

\section{Disabilitas Tunagrahita di Desa Karangpatihan}

Sejarah 'desa idiot' di Desa Karangpatihan ini berawal dari keyakinan warga bahwa pada tahun 1963 - 1967 terjadi sebuah krisis pangan dikarenakan serangan hama tikus yang menyerang sektor pertanian pada Desa Karangpatihan sehingga pada masa itu masyarakat kekurangan pangan (Novel, 2018). Bertepatan dengan terjadinya krisis tersebut banyak penduduk desa yang sedang hamil sehingga krisis pangan yang terjadi berdampak pada gizi dan tumbuh kembang kehamilan (wawancara dengan Kepala Desa Karangpatihan, Eko Mulyadi, 23 Juni 2021). 
Minimnya akses untuk masyarakat yang mengalami disabilitas tunagrahita di Desa Karangpatihan menjadi faktor utama dalam proses perkembangan mereka. Banyak penyandanag tunagrahita yang tidak bekerja sehingga mereka harus menggantungkan hidup dari bantuan warga lain, bantuan pemerintah, serta bantuan dari donatur. Mereka juga tidak mendapatkan pendidikan yang layak. Mayoritas penyandang tunagrahita di Desa Karangpatihan berusia lebih dari 25 tahun. Dalam proses pembuatan identitas kependudukan mereka juga mengalami kesulitan, dalam hal ini pemerintah desa terkesan membiarkan mereka sehingga kewajiban dan hak sebagai warga negara tidak dapat dilaksanakan. Seiring dengan berjalannya waktu dan berbagai perubahan yang dilaksanakan oleh pemerintah Desa Karangpatihan maka masalah-masalah seperti itu sudah dapat terselesaikan. Pemerintah Desa Karangpatihan bermitra dengan dengan Balai Besar Rehabilitasi Sosial Bina Grahita (B2RSBG) dalam pemetaan kategori tunagrahita, sehingga pemerintah desa memiliki data kategori tunagrahita yaitu: 57 orang masuk dalam kategori tunagrahita ringan, 37 dalam kategori sedang, dan 4 lainnya pada kategori berat.

Tabel 1. Klasifikasi Jumlah Penyandang Tunagrahita Berdasarkani Kriteria

\begin{tabular}{|l|l|l|}
\hline No & Kategori Tunagrahita & Jumlah \\
\hline 1 & Tunagrahita ringan & 57 \\
\hline 2 & Tunagrahita sedang & 36 \\
\hline 3 & Tunagrahita berat & 4 \\
\hline & Jumlah & 97 \\
\hline
\end{tabular}

\section{Peran Pemerintah Desa Karangpatihan dalam Penjaminan Hak Disabilitas Penyandang Tunagrahita}

Hak disabilitas telah diatur dalam Undang-undang nomor 8 tahun 2016 tentang Penyandang Disabilitas. Dalam undang undang tersebut menjelaskan penyandang disabilitas adalah orang - orang yang mengalami keterbatasan fisik, intelektual mental atau sensorik dengan jangka waktu yang lama sehingga dalam pemenuhan kegiatan sehari hari mendapatkan kesulitan. Terdapat 22 poin hak penyandang disabilitas dalam undang undang nomor 8 tahun 2016 antara lain hak hidup, hak bebas dari stigma, hak privasi, hak untuk mendapatkan keadilan dan perlindungan hukum, pendidikan, hak atas pekerjaan kewirausahaan dan koperasi, kesehatan, politik, keagamaan, keolahragaan, kebudayaan dan pariwisata, kesejahteraan sosial, aksebilitas, pelayanan publik, perlindungan dari bencana, habilitas dan rehabilitasi, konsensi, pendataan, hidup secara mandiri dan dilibatkan dalam masyrakat, berekspresi berkomunikasi dan memperoleh informasi, berpindah tempat dan kewarganegaraan dan bebas dari tindakan diskriminasi, penelantaran, penyiksaan dan eksploitasi. 
Pemilik tanggungjawab besar terhadap masalah di desa adalah pemerintah desa. Pemerintah desa sepenuhnya menjadi lembaga yang bertanggung jawab dalam menjamin keberlangsungan hak para penyandang disabilitas tunagrahita di Desa Karangpatihan. Permasalahan yang ada oleh penyandang tunagrahita di Desa Karangpatihan sangat kompleks, dari permasalahan pendidikan hingga lapangan kerja. Pemerintah desa berperan aktif dalam menyikapi masalah tersebut, hal terpenting yang harus ditanamkan pada masyarakat disabilitas tunagrahita tersebut adalah sifat kemandirian, hal ini dimaksudkan agar mereka tidak dipandang sebelah mata oleh masyarakat lainnya. Oleh karenanya pemerintah desa menjawab dengan memberikan penguatan pendidikan masyarakat untuk mereka agar tujuan hidupnya dapat terpenuhi (Januar Mahardhani, 2018; Yuliana et al., 2019).

Dalam hal pendidikan pemerintah desa menyiapkan pendidikan berbasis ekonomi dimana para penyandang tunagrahita diberdayakan dan dilatih untuk membuat keset. Pembuatan keset ini dinilai sebagai salah satu pendidikan dimana melatih motorik para penyandang disabilitas untuk lebih fokus terhadap sesuatu. Kemudian hasil dari pembuatan keset tersebut dijual dan hasil dari penjualan di serahkan kepada penyandang tunagrahita yang tergabung didalam kelompok sosial tersebut. Tidak hanya itu pemerintah desa juga mengembangkan potensi yang lain yaitu budidaya lele. Berdasarkan wawancara yang dilakukan dengan kepala desa, sebagian dari mereka khususnya laki laki diberikan pelatihan sekaligus praktek lapangan dalam budidaya lele.

Dalam perananya pemerintah desa telah membagi hak utama disibiltas penyandang tunagrahita di Desa Karangpatihan menjadi tiga bagian (wawancara dengan Kepala Desa Karangpatihan, Eko Mulyadi, 26 Juni 2021), yaitu:

1. Hak sipil dan politik.

Sebagai pelayan masyarakat, perangkat desa harus bekerja lebih, apalagi dengan adanya masyarakat yang memiliki keterbatasan intelektual. Untuk melakukan perekaman E-KTP pemerintah desa secara langsung mendatangi warga disabilitas tunagrahita tersebut dengan dibantu para warga lainnya. Dengan adanya kerjasama antara pemerintah dan masyarakat maka proses pencatatan atau pembuatan data administratif baru untuk penyandang disabilitas tunagrahita menjadi maksimal. Kemudian dalam hak politik. Dalam pemilihan kepala desa dan pemilihan umum terdapat akomodasi tersendiri bagi penyandanag disabilitas tunagrahita sehingga mereka dapat menyalurkan hak pilihnya, antara lain pemerintah desa menciptakan layanan khusus untuk penjemputan masyarakat disabilitas tunagrahita tersebut sampai di depan rumah masing-masing. 
2. Hak ekonomi, sosial, dan budaya. Dalam pengelompokan ini desa memberdayakan 57 penyandang tunagrahita pada level ringan dalam menunjang perekonomian serta menjamin kesejahteraan mereka, tidak hanya itu mereka juga dididik melalui program pemberdayaan yang dinisiasi oleh pemerintah desa misalnya pembuatan kerajinan, ternak dan bududaya tanaman. Pada pelaksanaannya tidak jarang pemerintah desa mengajak pihak ketiga dan keempat dalam pelaksanaan program, yaitu institusi pendidikan, sektor swasta baik yang berasal dari dalam negeri maupun luar negeri, dan media. Pemberdayaan dengan 'pentahelix model' inilah yang saat ini dikembangkan oleh pemerintah Desa Karangpatihan.

3. Hak khusus yang meliputi kemampuan dalam berwirausaha serta socialpreneur,. Dimana secara bebas mereka mengembangkan potensi yang dimiliki oleh masing-masing individu disabilitas tunagrahita, misalnya dalam menjual dan mengelola kebutuhan dasar mereka sampai dengan pemenuhan kebutuhan yang bersifat privasi.

Dalam upaya kepedulian pemerintah desa terhadap tunagrahita maka pemerintah Desa Karangpatihan juga mencanangkan program catur karya dimana antara konsep perkembangan ekonomi masyarakat penyandang tunagrahita seiring berjalan dengan program pendidikan.

\section{Implementasi dalam Pemenuhan Hak Disabilitas Tunagrahita sesuai Undang-Undang Nomor 8 Tahun 2016 di Desa Karangpatihan}

Dalam Undang-Undang nomor 8 tahun 20016 tentang Penyandang Disabilitas disebutkan bahwa pelaksanaan penghormatan, perlindungan dan pemenuhan hak disabilitas menjadi tanggung jawab bersama, yaitu pemerintah pusat maupun daerah, dalam penjelasan dapat diartikan bahwa pemerintahan desa juga mempunyai peran yang besar terhadap tanggungjawab yang dimaksud sehingga desa dapat digunakan sebagai penjamin atas keberlangsungan kehidupan mereka. Pemerintah Desa Karangpatihan hingga saat ini telah berhasil mengubah pandangan masyarakat terhadap 'desa idiot' menjadi desa kreatif dengan penjaminan atas implementasi dari Undang-Undang nomor 8 tahun 2016 tentang Penyandang Disabilitas pasal 5. Berdasarkan wawancara dengan kepala desa Karangpatihan, Eko Mulyadi (26 Juni 2021) berikut adalah pelaksanaan pemenuhan hak disabilitas untuk penyandang tunagrahita yang telah pemerintah desa lakukan.

a. Hidup.

Kebasan dari penelantaran adalah bagian dari implementasi hak hidup, dimana masyarakat tunagrahita terus diperjuangan dalam mendapatkan identitas mereka yang sama sengan warga negara yang lain. Tunagrahita mendapatkan perawatan tidak hanya dari pihak pemerintahan, 
namun juga berkolaborasi dengan warga lainnya atau pihak dari luar Desa Karangpatihan, sehingga sinergi yang terbentuk menjadi kekuatan untuk merubah eksistensi masyarakat penyandang disabilitas tunagrahita.

b. Hak bebas dari stigma.

Bebas dari stigma adalah perwujudan dari penyandang disabilitas yang terbebas dari pelecehan, penghinaan, dan aktivitas perundungan. Hak ini menjamin kaum disabilitas dari pelabelan negatif, bentuk dari usaha pemerintah desa adalah membuat komunitas tunagrahita sehingga akan terbentuk lembaga yang siap melindungi, yaitu komunitas Rumah Harapan Karangpatihan Bangkit.

c. Privasi.

Setiap manusia memiliki privasi masing-masing, tentu juga bagi penyandang tunagrahita dimana mereka diberikan privasi sepenuhnya selayaknya wargaa masyarakat lainnya. Pemerintah Desa Karangpatihan juga menerbitkan kebijakan terkait dengan hak penyandang disabilitas tunagrahita, diantaranya kebijakan pemberian sembako berupa bahan makanan pokok setiap bulannya untuk membantu keluarga yang berstatus tunagrahita.

d. Keadilan dan perlindungan hukum.

Penyandang tunagrahita di Desa Karangpatihan dijamin atas perlakuan yang sama dihadapan hukum, mereka juga di berikan kewenangan atas memiliki dan mewarisi harta dalam keluarga yang dimaksudkan untuk mengendalikan masalah terkait dengan waris dan agraria lainnya.

e. Pendidikan.

Implementasi dari hak pendidikan adalah pemerintah desa telah bekerjasama dengan B2RSBG untuk menyiapkan pola pendidikan yang khusus. Tentunya pola pendidikan yang dimaksud sesuai dengan kriteria penyandang tunagrahita yaitu selain dengan menerapkan kurikulum pengetahuan juga ketrampilan (softskill) yang disesuaikan dengan kondisi geografis Desa Karangpatihan.

f. Pekerjaan, kewirausahaan, dan koperasi.

Pemerintah Desa Karangpatihan berupaya dalam membuka peluang peluang usaha baru. Dapat dilihat bahwa desa juga mempersiapkan Rumah Harapan Karangpatihan Bangkit sebagai lembaga dalam mengembangkan potensi peluang usaha, seperti yang terlihat bahwa para penyandang tunagrahita sekarang mempunyai berbagai macam hewan ternak untuk dapat diproduksi daging dan telurnya serta usaha rumahan yaitu usaha mengayam atau membatik. 
g. Kesehatan.

Pemerintah desa telah bekerjasama dengan pusat kesehatan masyarakat (Puskesmas) dimana penyandang tunagrahita selalu di monitoring baik keadaan lingkungan tempat tinggal, kondisi kesehatan tubuh, bahkan tentang konsumsi pemenuhan gizi. Pemerintah Desa Karangpatihan juga menganggarkan dalam Anggaran Pendapatan dan Belanja Desa (APBDes) tentang pemenuhan gizi untuk penyandang tunagrahita.

h. Politik.

Kebebasan berpendapat dalam pemilihan calon bahkan perekrutan calon kepala desa atau perangkat desa sangat terbuka. Para penyandang disabilitas ringan bebas dalam mengajukan dirinya sebagai calon kontestan politik. Tidak hanya itu pemerintah desa juga menyediakan akses seperti kendaraan dalam proses pemilihan untuk meningkatkan partisipasi politik masyarakat tunagrahita di Desa Karangpatihan.

i. Keagamaan.

Dalam pemenuhan hak keagamaan pemerintah Desa Karangpatihan juga menyediakan sarana beribadatan yang ramah dengan penyandang disabilitas. Lebih dari itu bahkan mereka ada yang menjadi marbot masjid. Pemerintah Desa Karangpatihan juga memberi kebebasan dalam berkeyakinan sehingga tidak ada intervensi dari pihak pemerintah megharuskan salah satu agama.

j. Keolahragaan.

Pemerintah Desa Karangpatihan menyiapkan lahan untuk berolahraga yang dapat dilaksanakan oleh setiap orang tanpa melihat mereka normal atau sebagai disabilitas. Pemerintah desa juga kerap mengadakan kegiatan olahraga yang dapat diikuti oleh para tunagrahita yaitu senam sehat yang dilaksanakan pada setiap hari Minggu.

k. Kebudayaan dan Pariwisata.

Setiap daerah pasti memiliki kebudayaan lokal masing-masing. Seiring dengan pendidikan dan ketrampilan yang diperoleh para penyandang tunagrahita mereka juga diajarkan dalam pengertian kebudayaan, kini pemerintah desa menyiapkan sanggar sebagai sarana mereka dalam berkreasi melalui kegiatan seni yang dapat berfungsi sebagai sarana pelestari budaya.

1. Kesejahteraan sosial.

Dalam pelaksanaan hak ini, pemerintah Desa Karangpatihan bekerjasama dengan pusat kesehatan, dinas kesehatan, dan rumah sakit baik rumah sakit umum dan khusus sebagai sarana 
jika diperlukan penanganan secara mendadak. Selain itu pemerintah desa juga mendaftarkan para penyandang disabilitas melalui jaminan dosial dan perlindungan sosial yang diberikan oleh pemerintah pusat, seperti Kartu Indonesia Sehat (KIS), Program keluarga Harapan (PKH), Kartu Sembako, serta Kartu Indonesia Pintar (KIP).

m. Aksesibilitas.

Pemerintah Desa Karangpatihan mempersilakan kepada masyarakat disabilitas penyandang tunagrahita untuk memanfaatkan fasilitas publik yang tersedia di desa selain itu mereka juga mempunyai hak untuk mendapatan akomodasi yang layak dari pemerintah desa pada saat mereka akan kontrol kesehatan ke rumah sakit khusus yang tidak ada di Kabupaten Ponorogo.

n. Pelayanan Publik.

Adanya pendampingan yang disediakan oleh pemerintah desa, dimana pendampingan ini tergabung dalam komunitas tunagrahita yang secara khusus memeberikan pelayanan serta pengertian bagi akses mendapatkan sesuatu yang bersifat administatif. Pemerintah desa juga membentuk tim untuk secara langsung memperhatikan apa kebutuhan mereka, hal ini pemerintah desa berkolaborasi dengan karang taruna desa.

o. Perlindungan dari Bencana.

Pemberian ruangan khusus bagi penyandang tunagrahita dalam upaya mengevakuasi jika terjadi bencana. Mereka juga membentuk elemen Desa Tangguh Bencana (Destana). Dalam pelaksanaan evakuasi secara khusus mereka mendahulukan mereka para penyandang tunagrahita yang terdampak, seperti kasus tanah gerak yang terjadi di Desa Karangpatihan. Hal ini dikarenakan Desa Karangpatihan terletak didataran tinggi dengan kontur tanah pegunungan.

p. Habilitasi dan Rehabilitasi.

Pemerintah Desa Karangpatihan memberikan habilitasi dan rehabilitasi sejak awal dan secara berkala serta selalu mengikutsertakan dalam perawatan bersama tenaga kesehatan sesuai dengan kebutuhan masing-masing individu yang menyandang tunagrahita.

q. Konsesi.

Potongan pembiayaan dalam segala kegiatan administrasi dalam layanan publik baik pemerintahan, kesehatan, pendidikan, dan sosial diberikan oleh pemerintah Desa Karangpatihan kepada keluarga penyandang tunagrahita, hal ini dimaksudkan untuk meringankan beban mereka yang mayoritas tidak mempunyai pekerjaan tetap. 
r. Pendataan.

Penyandang tunagrahita juga didata sebagai penduduk dalam kegiatan pendaftaran penduduk dan pencatatan sipil, selain itu mereka juga difasilitasi oleh desa untuk medapatkan dokumen kependudukan dan mendapatkan kartu penyandang disabilitas.

s. Hidup secara mandiri dan dilibatkan dalam masyarakat.

Kesetaraan merupakan prinsip dasar dalam melibatkan mereka dalam masyarakat, pemerintah desa memfasilitasi dengan penyediaan alat bantu yang dibutuhkan oleh para penyandang tunagrahita. Selain itu mereka juga mendapatkan pelatihan dan pendampingan untuk dapat hidup mandiri baik dari pemerintah desa, dinas, atau pihak swasta.

t. Berekspresi, berkomunikasi, dan memperoleh informasi.

Pemerintah Desa Karangpatihan memberikan kebebasan untuk penyandang disabilitas berekspresi dan berpendapat. Selain itu pemerintah desa juga menyiapkan papan informasi yang berada dalam Rumah Harapan Karangpatihan Bangkit. Selanjutnya pemerintah desa juga menyiapkan tenaga ahli untuk healing kepada para penyandang disabilitas agar mereka juga mendapatkan ketenangan.

u. Berpindah tempat dan kewarganegaraan.

Pemerintah Desa Karangpatihan memfasilitasi untuk masyarakatkan penyandang tunagrahita untuk berpindah tempat dan kewarganegaraan, meskipun sampai dengan saat ini belum ada proses pindah yang dilakukan oleh mereka.

v. Bebas dari tindakan diskriminasi, penelantaran, penyiksaan, dan ekploitasi. Pelaksanaannya pemerintah Desa Karangpatihan benar-benar telah mengawal masyarakat tunagrahita untuk tidak mendapatkan diskriminasi, penelantaran, penyiksaan, dan eksploitasi, mereka akan terus dalam pantuan dan mendapatkan perlindungan dari segala bentuk kekerasan fisik, psikis, ekonomi, dan seksual.

\section{Model Kolaborasi dalam Analisa Pemenuhan Hak Disabilitas Tunagrahita Desa Karangpatihan}

Dua puluh dua hak yang ada dalam pasal 5 Undang-Undang nomor 8 tahun 2016 tentang Penyandang Disabilitas dapat diimplementasikan oleh pemerintah Desa Karangpatihan, kolaborasi antar aktor menjadi strategi percepatan dalam penanganan masalah disabilitas penyandang tunagrahita, hal ini tentunya akan menjadi awal yang baik bagi Desa Karangpatihan untuk menghapus stigma desa idiot. Kolaborasi antar aktor dalam pelaksanaannya melibatkan berbagai pihak yaitu 
pusat kesehatan masyarakat, lembaga swasta, serta institusi pendidikan. Pola kolaborasi yang terbentuk dari aktivitas pemenuhan kebutuhan hak disabilitas ini menjadi sebuah bentuk kerjasama kolaborasi yang disebut dengan triple helix. Triple helix adalah model inovasi yang dipelopori oleh Etzkowitz \& Leydesdorff. Keberadaan model triple helix akan menciptakan sebuah kerjasama antar tiga aktor yang ada di Desa Karangpatihan yaitu aktor akademik, bisnis, dan pemerintah. Ketiga aktor tersebut berupaya untuk memberikan layanan terbaik menurut kemampuan masing-masing.

Aktor akademik yang dimaksud adalah perguruan tinggi, dari hasil observasi dan wawancara yang dilakukan bersama kepala desa menyebutkan bahwa banyak perguruan tinggi yang datang ke Desa Karangpatihan baik memberikan bantuan secara finansial ataupun memberikan pemikiran dalam rangka untuk pemberdayaan masyarakat (Suciati, 2021; Wahyuni, 2020; Widodo, 2020; Wulandari et al., 2019). Masyarakat berkebutuhan khusus sangat membutuhkan peran akademisi dalam rangka memberikan penguatan pada aspek kemandiriannya, sehingga pendampingan melalui berbagai aktivitas pendidikan non formal atau pelatihan-pelatihan sangat diberikan ruang oleh pemerintah Desa Karangpatihan.

Selain itu unsur pendidikan juga memberikan masukan dalam rangka penyusunan kurikulum ketrampilan yang ada di sekolah, institusi pendidikan tinggi juga tidak jarang mengirimkan dosennya untuk membantu dalam proses pengajaran di sekolah baik melalui program yang ada di institusi atau melalui program yang diberikan oleh pemerintah. Unit yang kedua dalam keberhasilan kolaborasi di Desa Karangpatihan adalah dari pihak swasta atau unsur bisnia, sepertihalnya yang disampaikan oleh bapak Kepala Desa Karangpatihan bahwa pihak swasta dilibatkan dalam rangka memberikan bantuan atau stimulus kepada para penyandang disabilitas yang ada baik dalam bentuk bantuan keuangan atau bantuan barang yang bisa dimanfaatkan oleh masyarakat. Tentunya hal ini sangat membantu para penyandang disabilitas sebagai bentuk pemenuhan hak hidup secara mandiri dan dilibatkan dalam masyarakat.

Unsur yang ketiga dalam keberhasilan kolaborasi adalah peran pihak pemerintah dalam rangka untuk pemenuhan hak disabilitas. Pemerintah memegang peranan penting dalam keberhasilan ini, baik pemerintah desa ataupun pemerintah daerah. Regulasi yang dikeluarkan oleh pemerintah daerah dalam rangka memberikan hak kepada para penyandang disabilitas sudah dikeluarkan oleh pemerintah Kabupaten Ponorogo melalui berbagai peraturan yang ada, seperti keluarnya Peraturan Daerah Kabupaten Ponorogo nomor 3 tahun 2009 tentang Bangunan Gedung, disebutkan bahwa pada pasal 37 ayat 2 yaitu setiap bangunan umum harus memiliki kelengkapan prasarana dan sarana bangunan yang memadai meliputi fasilitas bagi penyandang cacat sesuai ketentuan persyaratan teknis aksesibilitas pada bangunan umum dan lingkungan, pada pasal 39 ayat 2 yaitu kemudahan hubungan 
ke, dari dan di dalam bangunan gedung sebagaimana meliputi tersedianya fasilitas dan aksesbilitas yang mudah, aman, dan nyaman termasuk bagi penyandang cacat dan lanjut usia, dalam ayat 3 yaitu penyediaan fasilitas dan aksesbilitas harus mempertimbangkan tersedianya hubungan horisontal dan vertikal antar ruang dalam bangunan gedung, akses evakuasi, termasuk bagi penyandang cacat dan lanjut usia.

Peraturan Daerah Kabupaten Ponorogo nomor 3 tahun 2016 tentang Perubahan atas Peraturan Daerah nomor 14 tahun 2011 tentang Retribusi Jasa Umum, dalam pasal 1 ayat 89 disebutkan bahwa pemerintah juga memberikan fasilitas kendaraan khusus untuk para penyandang cacat. Selanjutnya pada Peraturan Daerah Kabupaten Ponorogo nomor 4 tahun 2020 tentang Penyelenggaraan Kabupaten Layak Anak yang didalamnya lebih memberikan aturan kepada Ibu hamil agar memberikan asupan vitamin yang cukup dalam rangka menjaga anak yang dilahirkannya dari kecacatan (pasal 33, 38, dan 64).

\section{KESIMPULAN}

Pemerintah Desa Karangpatihan melaksanakan pemenuhan hak disabilitas untuk penyandang tunagrahita sebanyak dua puluh dua sesuai dengan peraturan yang ada, yaitu: hidup, hak bebas dari stigma, privasi, keadilan dari perlindungan hukum, pendidikan, pekerjaan; kewirausahaan; dan koperasi, kesehatan, politik, keagamaan, keolahragaan, kebudayaan dan pariwisata, kesejahteraan sosial, aksesbilitas, pelayanan publik, perlindungan dari bencana, habilitasi dan rehabilitasi, konsensi, pendataan, hidup secara mandiri dan dlibatkan dalam masyarakat, bereksperimen; berkomunikasi; dan memperoleh informasi, berpindah tempat dan kewarganegaraan, serta bebas dari tindakan diskriminasi, penelantaran, penyiksaan, dan ekploitasi. Dari pemenuhan hak disabilitas tersebut Pemerintah Desa Karangpatihan berkolaborasi melalui konsep triple helix yaitu melibatkan unsur akademik, bisnis, dan pemerintah yang ketiga saling bersinergi untuk memberikan layanan terbaik kepada penyandang disabilitas.

\section{DAFTAR PUSTAKA}

Andriana, L. (2017). Kesejahteraan Sosial Tunagrahita di Ponorogo. Inklusi, 4(1), 25. https://doi.org/10.14421/ijds.040102

Anugrawati, D. N., \& Pradana, G. W. (2021). PEMBERDAYAAN MASYARAKAT DALAM MENINGKATKAN PENDAPATAN MASYARAKAT TUNAGRAHITA MELALUI PROGRAM RUMAH HARAPAN (STUDI KASUS DI DESA KARANGPATIHAN KECAMATAN BALONG KABUPATEN PONOROGO). Publika, 135-144. 
https://doi.org/10.26740/PUBLIKA.V9N1.P135-144

Cahyono, S. A. T. (2017). Penyandang Disabilitas: Menelisik Layanan Rehabilitasi Sosial Difabel pada Keluarga Miskin. Media Informasi Penelitian Kesejahteraan Sosial, 41(3), 239-254. https://doi.org/10.31105/MIPKS.V41I3.2257

Dewi, D. S. K. (2016). Model Pemberdayaan Masyarakat Tunagrahita di Kampung Idiot Kabupaten Ponorogo. Otoritas: Jurnal Ilmu Pemerintahan, 6(1), 21-27. https://doi.org/10.26618/OJIP.V6I1.35

Gafara, C., Riyono, B., \& Setiyawati, D. (2017). Peran Karang Taruna Dalam Pemberdayaan Penyandang Disabilitas Di Desa Karangpatihan, Kabupaten Ponorogo Dan Implikasinya Terhadap Ketahanan Ekonomi Keluarga. Jurnal Ketahanan Nasional, 23(1), 37-48. https://doi.org/10.22146/JKN.18295

Hasanah, D. R. N. (2020). Analisis Model Pemberdayaan Masyarakat Pada Warga Tunagrahita Di Desa Karangpatihan, Kecamatan Balong, Kabupaten Ponorogo. IAIN Ponorogo.

Ismandari, F. (2019). Situasi Disabilitas. Pusat Data Dan Informasi Kementrian Kesehatan RI, 1-10. Januar Mahardhani, A. (2018). PEMBERDAYAAN MASYARAKAT MELALUI PENDIDIKAN NONFORMAL BERKARAKTER CINTA TANAH AIR. Jurnal Pancasila Dan Kewarganegaraan. https://doi.org/10.24269/jpk.v3.n2.2018.pp56-63

Kusumawati, A., \& Adi, A. S. (2020). Tanggapan Penyadang Tunagrahita Ringan Atas Pemenuhan Hak Politik Dalam Pilkades 2019 ( Studi Desa Karangpatihan Kecamatan Balong Kabupaten Ponorogo ). Kajian Moral Dan Kewarganegaraan, 08(02), 544-558.

Mahardhani, A. J. (2017). Peran Pemerintah Kabupaten Ponorogo dalam Pengembangan Kawasan Selingkar Wilis. Jurnal Ilmiah Manajemen Publik Dan Kebijakan Sosial. https://doi.org/10.25139/jmnegara.v1i1.284

Nasution, H. A., \& Marwandianto, M. (2019). Memilih dan Dipilih, Hak Politik Penyandang Disabilitas dalam Kontestasi Pemilihan Umum: Studi Daerah Istimewa Yogyakarta. Jurnal HAM, 10(2), 161-178. https://doi.org/10.30641/HAM.2019.10.161-178

Ndaumanu, F. (2020). Hak Penyandang Disabilitas: Antara Tanggung Jawab dan Pelaksanaan oleh Pemerintah Daerah. Jurnal HAM, 11(1), 131-150.

https://doi.org/10.30641/HAM.2020.11.131-150

Ramanda, A. N. (2008). Dinamika penerimaan ibu terhadap anak tuna grahita. Universitas Islam Negri Syarif Hidayatulloh. 
Rika, H., Dewi, K., Putri, R., Hariyanti, P., Hastuti, S., Kumala, R., Rezanti, D., Pramana, P., Sadaly, H., Kerja, K., Kertas, S., \& Smeru, K. (2020). Kendala Mewujudkan Pembangunan Inklusif Penyandang Disabilitas. www.smeru.or.id.

Rulianingsih, S., \& Suyanto, T. (2018). Strategi Kepala Desa Dalam Memberdayakan Masyarakat Tunagrahita Untuk Membangun Good Citizenship Di Kampung Idiot Desa Karangpatihan Kecamatan Balong Kabupaten Ponorogo. Kajian Moral Dan Kewarganegaraan, 6(3), 10461060.https://jurnalmahasiswa.unesa.ac.id/index.php/jurnal-pendidikankewarganegaraa/article/view/26147

Safira, N. I., \& Roseta, C. I. (2021). MODEL KEWIRAUSAHAAN SOSIAL PADA KOMUNITAS MUSLIM RUMAH HARAPAN KARANGPATIHAN BANGKIT. KABILAH: Journal of Social Community, 6(1), 26-43. https://doi.org/10.35127/KBL.V6I1.4411

Suciati. (2021, September 16). TIM P3D Unipma Madiun Latih PKK Karangpatihan Ponorogo Membuat Tas dan Dompet Anyaman . Https://Www.Timesindonesia.Co.Id. https://www.timesindonesia.co.id/read/news/370525/tim-p3d-unipma-madiun-latih-pkkkarangpatihan-ponorogo-membuat-tas-dan-dompet-anyaman

Susanto, H. H. (2021). Pemberdayaan Ekonomi Masyarakat di Kampung Idiot Karangpatihan Balong Ponorogo. JoIE: Journal of Islamic Economics, $1(1), \quad 2021$. https://jurnal.iainponorogo.ac.id/index.php/joie/article/view/3080

Wahyuni, E. T. (2020, September 30). Disabilitas Berkarya - Bangun Desa Binaan dengan PHP2D UKM KWU Cendekia . Http://Unipma.Ac.Id. http://unipma.ac.id/berita/280/disabilitasberkarya---bangun-desa-binaan-dengan-php2d-ukm-kwu-cendekia

Widajati, S., \& Purnama, A. (2020). Implementasi Rehabilitasi Sosial bagi Tuna Grahita di Balai Besar Rehabilitasi Sosial Bina Grahita (B2rsbg) Kartini Temanggung. Media Informasi Penelitian ..., 255-266.

Widodo, A. A. (2020, July 23). Desa Karangpatihan jadi tempat Pelatihan Batik Ciprat Bersama Universitas Sebelas Maret Surakarta . Https://Madiunraya.Com. https://madiunraya.com/2020/07/desa-karangpatihan-jadi-tempat-pelatihan-batik-cipratbersama-universitas-sebelas-maret-surakarta/

Wulandari, R., Anjasari, H., Wulandari, N. D., Jayanti, M. N., \& Gunarhadi, G. (2019). PEMBERDAYAAN WARGA KETERBELAKANGAN MENTAL DI DESA KARANGPATIHAN PONOROGO MELALUI FRUTABLE GREDEN. Jurnal Pemberdayaan Masyarakat Universitas Al Azhar Indonesia, 1(2), 78-83. 
https://doi.org/10.36722/JPM.V1I2.342

Yuliana, W. D., Mahardhani, A. J., \& Utami, P. S. (2019). POLA PENDIDIKAN KARAKTER KEMANDIRIAN ANAK BERKEBUTUHAN KHUSUS TUNANETRA PADA PANTI ASUHAN TUNANETRA TERPADU AISYIYAH PONOROGO. EDUPEDIA, 3(1), 39-47. https://doi.org/10.24269/ED.V3I1.234 